\title{
Writ of Corbam Nobis Pleading of Last Resort?
}

\author{
Benjamin Neil \\ Retired Professor of Legal Studies \\ Towson University
}

Keywords: Coram nobis, pro se, appeal and guilty plea.

[It should be noted that only 15 states and the District of Columbia, as well as Federal criminal courts, recognize some form of the Writ of Coram Nobis.

For purposes of this exercise, the Maryland statutes will be used, as Maryland is in fact, one of the 15 states recognizing the Writ.]

\section{Fact Scenario}

On January 11, 1998, the Petitioner, Francis Debelius, appeared in the Circuit Court for Baltimore City. At that time, he plead guilty to one count of possession with the intent to distribute drugs, On February 19, 1998, he was sentenced to eighteen months of incarceration.

On August 12, 2013, he filed his pro se Coram Nobis petition challenging the validity of his guilty plea and the effectiveness of his defense counsel. The petition alleged that he had subsequently plead guilty in the Unites States District Court for the District of Maryland, on September 5, 2005 to one count of possession with intent to distribute. He further alleged that his prior state conviction had been used to qualify him as a career offender, resulting in his federal sentence being increased to 292 months, causing collateral consequences.

On September 5, 2013, the State filed a request for additional time to respond to the petition. On September 11, 2013, the Circuit Court for Baltimore City, issued an Order denying the petition.

On October 14, 2013, an appeal was filed with the Court of Special Appeals. On April25, 2015, the Court of Special Appeals vacated the judgment of the Circuit Court and remanded the matter for further proceedings.

Question \#1: Is the Petition for Writ of Coram Nobis the proper vehicle to attack the validity of this conviction 1 .

The Petitioner alleges that the Writ of Error Coram Nobis is the proper vehicle of relief in this case. The State concedes that he is not incarcerated on his state conviction and is not on parole or probation from his conviction. In addition, the State argued that he is not facing significant collateral consequences.

The Writ of error Coram Nobis is an "extraordinary remedy" available only in exceptional circumstances. United States vs. Morgan, 346 U.S. 502, 511 (1954). In order for the challenged error to be of sufficient magnitude, the error must have resulted in a complete miscarriage of justice and relief must be necessary to correct errors of fundamental or constitutional significance. Id at 512. In addition, the Petitioner must show that he is facing significant collateral consequences as a result of the prior conviction. Skok vs. State, $361 \mathrm{Md}$. 52, 79 (2000).

In the instant case, the Petitioner argues that he was convicted of possession with intent to distribute in the United States District Court of Maryland and as such, faced an enhanced sentence of 292 months. In any event, the Supreme Court has recognized that most criminalconvictions "do in fact entail adverse collateral consequences" as "subsequent convictions may carry heavier penalties." Morgan, 346 U.S. 511, 512-513. As such, in order to be considered "significant," a collateral consequence must be more substantial than the usual adverse consequences that flow from repeated forays in the criminal justice system. If an increase in sentencing guidelines ranges based on a single conviction constituted a significant collateral consequence, the virtually every prior conviction would be subject to Coram Nobis review. Coram Nobis would no longer be an exceptional remedy but rather a routine means for challenging all convictions. The Court's dockets would be inundated with petitions seeking to challenge old convictions and no conviction could reliably be considered final. Therefore, in this case, the Petitioner cannot effectively show he is suffering significant collateral consequences. 


\section{Question \#2: Did the Petitioner knowingly and voluntarily enter a guilty plea and did the Court comply with Rule 4-242?}

In this case, the Petitioner failed to exercise his right to withdraw his guilty plea in a timely fashion under Maryland Rule 4-424. Pleas.

Rule 4-242.Pleas

(h) Withdrawal of plea. At any time before sentencing, the court may permit a defendant to withdraw a plea of guilty, a conditional plea of guilty, or a plea of nolo contendere when the withdrawal serves the interest of justice. After the imposition of sentence, on motion of a defendant filed within 10 days, the court may set aside the judgment and permit the defendant to withdraw the plea of guilty, a conditional plea of guilty, or a plea of nolo contendere if the defendant establishes that the provisions of section (c) or (d) (e) of this Rule were not complied with or there was a violation of a plea agreement entered into pursuant to Rule 4-243. The court shall hold a hearing on any timely motion to withdraw a plea of guilty, a conditional plea of guilty, or a plea of nolo contendere.

Here, the Petitioner had ample amounts of time to withdraw his guilty plea prior to being sentenced, but failed to do so. In addition, he could have filed a motion within 10 days from the imposition of his sentence, but again failed to do so. Therefore, his failure to withdraw his guilty plea is tantamount to an admission of its validity.

Maryland Rule 4-242(c) provides that "the court may not accept a guilty plea until after "an examination of the defendant, on the record in open court conducted by the court, the State's Attorney, the attorney for the defendant, or any combination thereof. Whereupon, the court announces that it has determined and announces on the record that (1) the defendant is pleading voluntarily, with the understanding of the nature of the charge and the consequences of the plea and (2) there is a factual basis for the plea. Rule 4-242, does not require that the precise legal elements comprising the offense be communicated to the defendant as a prerequisite for a valid acceptance of a guilty plea. State v. Priet, 289 Md. 267, 288 (1981); Lovell v. State, 347 Md. 623 (2005). Instead, the rule simply requires that the explanation of the nature of the charge afford the defendant a basic understanding of the essential substance. Priet,at 288.

The petitioner here alleges that his procedural due process rights were violated when there was not an express advertisement of the nature of the charges against him. Because of the simplicity of the charge against him and the petitioner's ability to understand simple concepts, the evidence shown through the record illustrated that the Petitioner must have understood the charges against him. Maryland courts gave held that when the trial court's record does not indicate a previous explanation of the nature of the charge by counsel, then the court must determine "on a case by case basis the complexity of the charge, the personal characteristics of the accused, and the factual basis proffered to support the court's acceptance of the plea."State v. Daughtry, 419 Md. 35,72,18A.3d 60, 82 (2011) quoting Priet, 289 Md. At 277,424 A.2d at 354 (emphasis added). The Maryland court has also characterized possession with intent to distribute as an offense that is readily understandable Gross v. State, 186 Md. App. 320, 342, 973 A. 2d895,908 (2009) cert denied $410 \mathrm{Md} .560$ (2009).In addition to the charge being one the court has characterized as readily understandable; the Petitioner shows no characteristics that would impede him from understanding the elementary nature of the charges being brought against his record.

\section{Question \#3: Is the Petitioner entitled to challenge his conviction by a Coram Nobis proceeding, when other remedies are available?}

A petition for writ of error Coram Nobis is a collateral challenge of last resort to a criminal conviction. Coram Nobis is not available if any other statutory or common law remedy is available. Skok v. State $361 \mathrm{Md}$. 52, 80, 760 A. $2 d 647$ (2000). The burden of proof rests with the Petitioner Id., $361 \mathrm{Md}$. At 80. Furthermore, A Corum Nobis petitioner must establish that he or she is facing significant collateral consequences as a result of the challenged conviction. The purpose of the writ is to bring before the court, facts which were not brought into issue at the trial of the case, and which were material to the validity and regularity of the proceedings, and which, if known by the court, would have prevented the judgment. Ruby v. State 353 Md. 100, 105, 724 A.2d 673 (1999). The grounds for challenging the criminal conviction must be of a constitutional, jurisdictional or fundamental character. Skok 361 Md. At 78. The modern scope of Corum Nobis embraces both errors of fact and law, which were material to the validity and regularity of the proceedings, and which, if know by the court, would have prevented the judgment. Id.

Here, the Petitioner failed to take advantage of other remedies available to him. He also failed to file a timely motion for leave to file an appeal and, in addition, failed to file a petition for post-conviction relief. Since he failed to take advantage of other remedies that were available to him, he cannot, now, challenge his conviction in the form of a writ of Corum Nobis. 
[As an aside:

"Baltimore's top prosecutor has filed a rarely used legal petition intended to vacate 3,778 convictions for possession of marijuana, arguing an extraordinary legal strategy is necessary to "right an extraordinary wrong."

In a highly unusual "Maryland v Maryland" filing in state court, State's Attorney, Marilyn Mosby, used a petition called "writ of error corum nobis" that allows a court to reopen cases when substantial error is found that wasn't apparent in initial judgments. The petition, if granted, could wipe out thousands of pot possession convictions."

(David McFadden, the Baltimore Sun. February 1, 2019)] 